\title{
Indirect Spectrophotometric Determination of Paracetamol Via Decolorization of Eriochrome Black-T With N-Bromosuccinimide
}

\author{
Zahraa J. Al-Gubouri ${ }^{1 *}$, Theia'a N. Al-Sabha ${ }^{2}$ \\ ${ }^{1,2}$ Department of Chemistry, College of Education for Pure Science, University of Mosul, Mosul, Iraq \\ E-mail: ${ }^{1 *} \underline{\text { Razzan.osm@gmail.com, }}{ }^{2} \underline{\text { dr_theiaa@yahoo.co.uk }}$
}

(Received March 27, 2020; Accepted May 11, 2020; Available online September 01, 2020)

DOI: 10.33899/edusj.2020.126846.1060, ( ) 2020, College of Education for Pure Science, University of Mosul.

This is an open access article under the CC BY 4.0 license (http://creativecommons.org/licenses/by/4.0/).

\begin{abstract}
:
A simple, precise and sensitive indirect spectrophotometric method is described for the assay of Paracetamol in its pure form and pharmaceutical formulations in the aqueous medium. The method is based on the oxidation of the Paracetamol with an excess of N-Bromosuccinimide (NBS) in alkaline medium and the residual oxidizing agent bleaches the purple-colored Eriochrome black-T (EBT) to colorless species which is measured at $516 \mathrm{~nm}$ at room temperature. Calibration graph is linear over 0.5$9 \mu \mathrm{g} \mathrm{mL}{ }^{-1}$ and molar absorptivity is $3.7 \times 10^{4} \mathrm{~L}_{\mathrm{mol}} \mathrm{mom}^{-1} \cdot \mathrm{cm}^{-1}$. The detection and quantification limits were 0.068 and $0.229 \mu \mathrm{gmL}^{-1}$ respectively. The accuracy (Average recovery \%) is 98.57, and Precision (RSD) is $\leq 1.5$. No interference effect has been observed from the excipients that exist in drug formulations. The method has been applied successfully in the determination of the Paracetamol in its commercial formulations (injection, syrup, and tablet), and compared favorably with other spectrophotometric methods used different reagents. The reaction mechanism for the oxidation of Paracetamol and EBT was postulated.
\end{abstract}

Keywords: Spectrophotometry, EBT, Paracetamol, Oxidation, NBS.

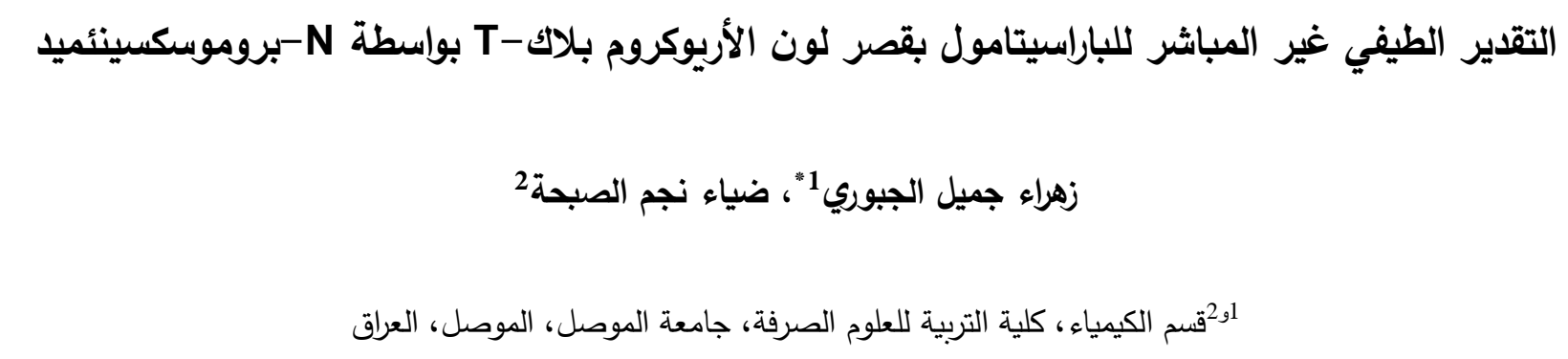

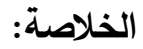

وصفت طريقة طيفية غير مباشرة بسيطة ومضبوطة وحساسة لتقدير دواء الباراسيتامول بصيغته النقية وفي مستحضراته

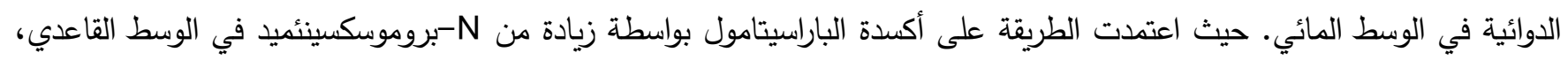

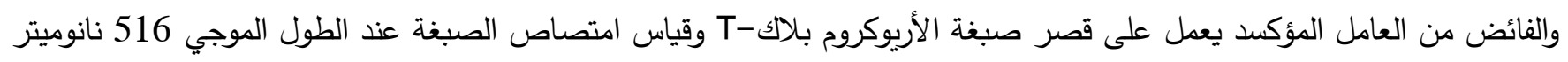
وذلك عند درجة حرارة المختبر ـ لقد وجد ان المنحنى القياسي خطي في مدى التركيز 0.5-9.0 مايكروغرام/مللتر ، وبلغت الامتصاصية 


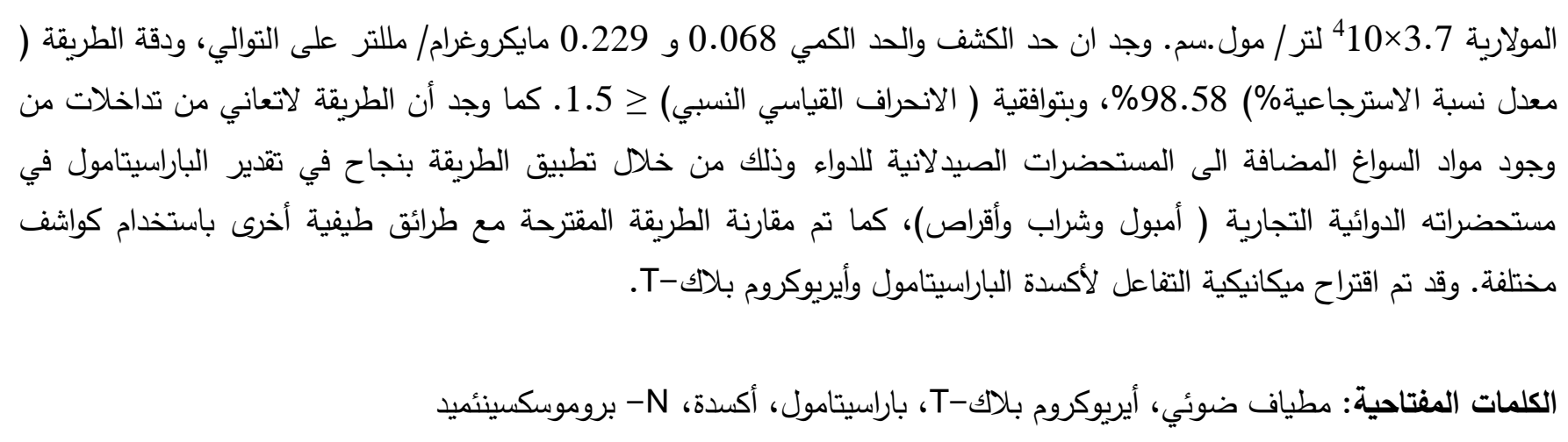

\section{Introduction}

Paracetamol also known as Acetaminophen, and chemically is $N$-(4-hydroxyphenyl) ethanamide, was first made in 1877 [1]. Paracetamol is one of the most popular drugs in the world and most used to treat fever and perhaps more common for the treatment of pediatrics. Paracetamol is also used during pregnancy and lactation [2-4], it is a harmful compound for a person's organism because it increases blood heat, and it remains active for an extended time [5]. The published spectrophotometric methods for quantification of Paracetamol within the literature are particularly relied on hydrolysis of the drug produced p-aminophenol and applying oxidative coupling [6-9] and diazotization coupling [10-12] methods using different reagents. There are also; other methods such as oxidation [13] and charge transfer complex formation reactions [14,15], or direct determination in the UV region [16-18] were described. However; some of these methods are either not sensitive and they suffer from interferences [16,17], or are carried on organic medium [14]. Other analytical techniques are additionally used for determination of Paracetamol, like HPLC [19,20], voltammetry [21,22] and chemiluminescence [23,24]. These techniques need highly sophisticated instruments. Eriochrome Black T (EBT) is an azo dye, which is known as mordant black that is used as an indicator in complexometric titrations for a metal ion determination, e.g. in the water hardness determination process. It was used for the determination of Gatifloxacin and Cefotaxime [25], Lidocaine [26], Antipsychotic Drugs [27], Dothiepin [28], Haloperidol [29], Rupatadine [30] and other drugs. However; those procedures depend on the formation of extractive ion-association complexes by organic solvents such as chloroform and methylene chloride. The present method is based on the oxidation of drugs by NBS and subsequent reaction with a fixed amount of EBT and the decrease in its absorbance was measured at $530 \mathrm{~nm}$. The method needs no extraction step; it is economic and successfully applied for analysis of Paracetamol in its pharmaceutical preparations. However, a survey of literature on Paracetamol drug revealed that spectrophotometric assay based on the use of NBS as an oxidizing reagent and EBT dye as an analytical reagent had not been yet stated. The present method describes a new simple and sensitive spectrophotometric procedure for the analysis of Paracetamol in an aqueous medium, based on the oxidation of Paracetamol by NBS in basic medium and the residual oxidant bleach the color of EBT dye and measured at $516 \mathrm{~nm}$.

\section{EXPERIMENTAL}

\section{Apparatus}

Absorbance and absorption spectra were recorded by a Shimadzu -1650 UV-Vis PC double beam spectrophotometer supplied with pair of a 1-cm path length silica cells, $\mathrm{pH}$ measurements were carried on by a combined glass electrode type Philips PW-9421 pH-meter. All calculations had been completed within the computing process in Excel program. 


\section{Journal of Education and Science (ISSN 1812-125X), Vol: 29, No: 3, 2020 (246-256)}

\section{Reagents}

All reagents and chemicals used of scientific grade were given by Fluka and BDH companies. $100 \mu \mathrm{gmL}^{-1}$ Paracetamol stock solution was prepared by dissolving a $0.01 \mathrm{~g}$ of pure form drug in 100 $\mathrm{mL}$ distilled water in the volumetric flask. The solution was kept in the refrigerator, $500 \mu \mathrm{gmL}^{-1} \mathrm{EBT}^{\mathrm{T}}$ solution was freshly prepared by dissolving $0.05 \mathrm{~g}$ in $100 \mathrm{~mL}$ distilled water in a volumetric flask, $5 \times 10^{-}$ ${ }^{3} \mathrm{M}$ N-Bromosuccinimide (NBS) solution was prepared by dissolving $0.089 \mathrm{~g}$ in $100 \mathrm{~mL}$ distilled water and $0.5 \mathrm{M}$ Potassium hydroxide was prepared by dissolving $2.8 \mathrm{~g}$ in $100 \mathrm{~mL}$ distilled water in a volumetric flask.

\section{Calibration graph procedure}

Aliquots of pure drug solution containing $0.5-9.0 \mu \mathrm{gmL}^{-1}$ of pure Paracetamol, transferred into a series of $10 \mathrm{~mL}$ calibrated flasks. To each flask, $0.6 \mathrm{~mL} \mathrm{KOH}(0.5 \mathrm{M})$ was added, followed by $0.8 \mathrm{~mL}$ NBS $\left(5 \times 10^{-3} \mathrm{M}\right)$ solution. The contents gently shaken and were left aside for $10 \mathrm{~min}$ at room temperature. Then, $2 \mathrm{~mL}$ of EBT solution $\left(500 \mu \mathrm{gmL}^{-1}\right)$ was added to each flask. The solutions were diluted to the mark with distilled water. The absorbance was measured at $516 \mathrm{~nm}$ after 10 min versus a reagent blank.

\section{Analysis of pharmaceutical formulations Tablet}

10 tablets Paracetamol (each tablet containing 500 mg Paracetamol) were finely powdered; an accurate weighed powder equivalent to one tablet was dissolved in $50 \mathrm{~mL}$ distilled, then filtered and the solution was made to $100 \mathrm{~mL}$ with distilled water in a volumetric flask. The resultant solution was further diluted and followed the calibration graph procedure.

\section{Injection}

The contents of one ampoule (containing $600 \mathrm{mg} / 5 \mathrm{~mL}$ Paracetamol) was diluted to $1 \mathrm{~L}$ with distilled water to obtain $600 \mu \mathrm{gmL}^{-1}$. Further dilution was made by distilled water to get the concentration of $100 \mu \mathrm{gmL}^{-1}$ and followed the calibration graph procedure.

Syrup

A $5 \mathrm{~mL}$ of antipyrol syrup ( containing $0.120 \mathrm{~g}$ Paracetamol) was diluted with distilled water in $100 \mathrm{~mL}$ measuring flask to obtain $1200 \mu \mathrm{gmL}^{-1}$. Then further dilution was made to obtain the applicable concentration range and followed the calibration graph procedure

\section{Results and Discussion}

EBT is a darkish blue dye as powder and its solution becomes darkish purple color in distilled water. It was observed that the purple color of EBT was bleached by strong oxidizing agents. However; the proposed method primarily based on the oxidation of Paracetamol by adding a fixed amount of NBS in basic medium, and left for a specific time for the completion of the oxidation of Paracetamol. Then the unreacted NBS was reacted with known amount of EBT; the absorbance was measured at $516 \mathrm{~nm}$. The decrease of NBS concentration upon oxidation of known concentration of drug lead to increase the absorbance at $516 \mathrm{~nm}$; this is due to the decolorization of EBT dye by the NBS, which depends on the Paracetamol concentration. The discoloration was caused by the destruction of the dye with NBS (Scheme 1). The increasing concentration of Paracetamol, lead to decreasing in the concentration of NBS for bleaching EBT and lead to increase the absorbance at $516 \mathrm{~nm}$ which is proportional to Paracetamol concentration (Fig. 1). 

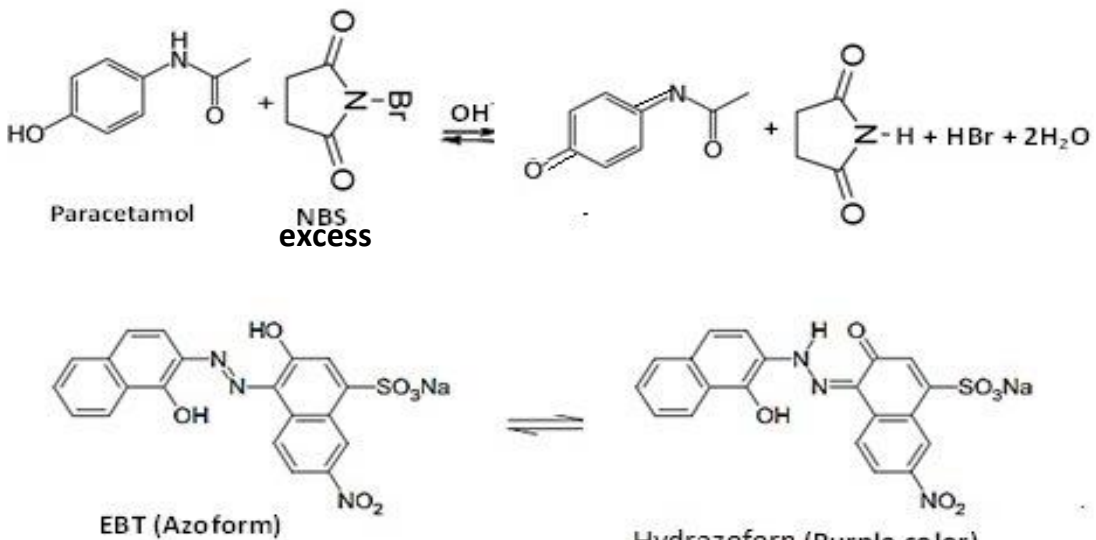

Hydrazoforn (Purple color)
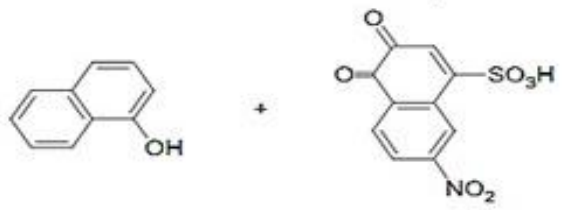

1-naphthol

3,4-dihydro-3,4-dioxo7-nitronaphthalene-
1 -sulfonic acid

\section{Scheme: Proposed mechanism for oxidation of EBT by NBS}

EBT showed an absorption band with $\lambda_{\max }$ at $516 \mathrm{~nm}$ in an aqueous medium (Fig. 1). The upper limit concentration of EBT was selected by plotting the absorbance of increasing amounts of dye against distilled water at $\lambda_{\max }$ and was found $100 \mu \mathrm{g} \mathrm{mL}$ (Fig. 2) which was selected in subsequent experiments.

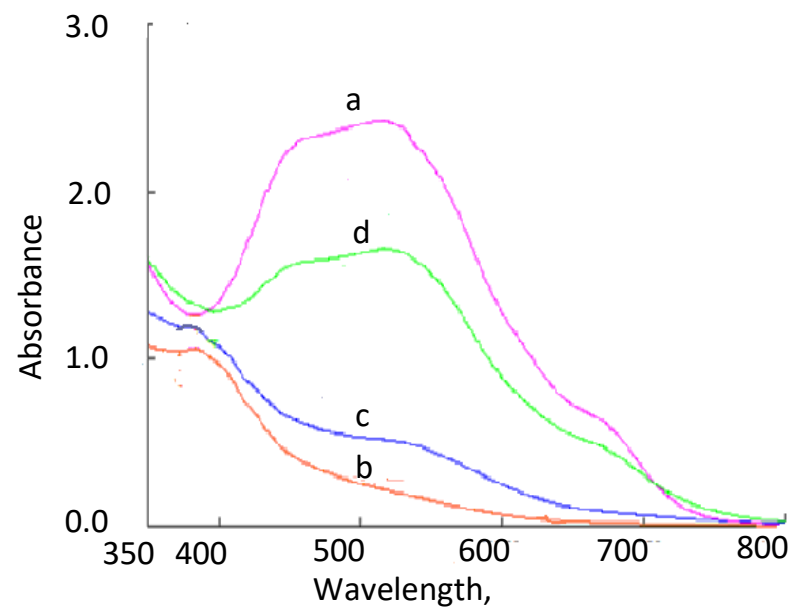

Figure1: Absorption spectra of $100 \mu \mathrm{gmL}^{-1} \mathrm{EBT}$ in the presence of a base (a) in the absence and (b) in the presence of $5 \times 10^{-3} \mathrm{M}$ NBS with (c) $2 \mu \mathrm{gmL} L^{-1}$ and (d) $6 \mu \mathrm{gmL} \mathrm{L}^{-1}$ of Paracetamol.

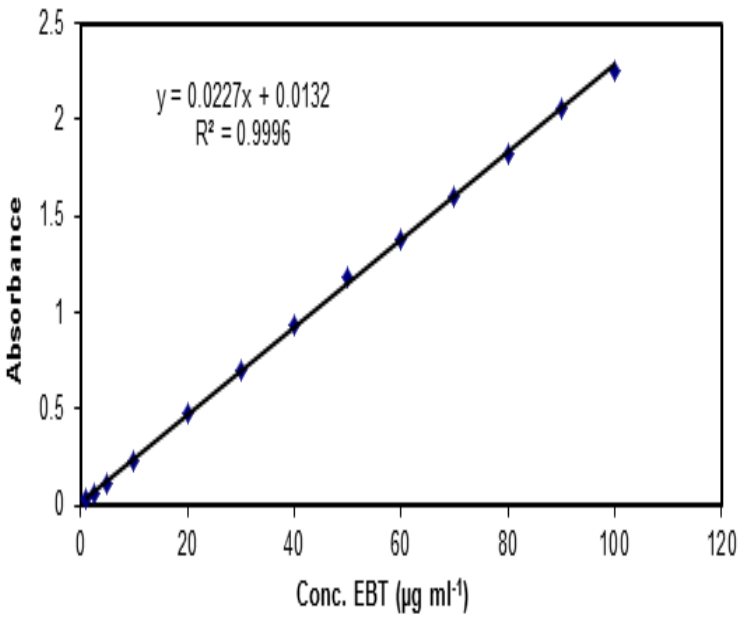

Figure 2: Calibration graph of EBT in the presence of $\mathrm{KOH}$ 


\section{Optimization of conditions}

In order to establish the experimental conditions for high sensitivity of the method, the effect of various parameters such as oxidizing agent, base, temperature and time were studied and optimized.

\section{Effect of oxidant and concentration}

Various oxidizing agents such as potassium chromate, potassium dichromate, potassium iodate and NBS with a concentration of $5 \times 10^{-3} \mathrm{M}$ had been tested for bleaching of $100 \mu \mathrm{g} \mathrm{mL}^{-1}$ EBT within the presence of $1 \mathrm{~mL}$ of $0.5 \mathrm{M} \mathrm{KOH}$. The reaction mixture was left for $10 \mathrm{~min}$; then a volume was completed to $10 \mathrm{~mL}$ with distilled water and the absorbance was measured at a suitable wavelength. It was found that NBS is the best oxidant ( Figure 3), and $0.8 \mathrm{~mL}$ of $5 \times 10^{-3} \mathrm{M}$ is sufficient to bleach the dye, (Fig. 4), which is recommended in this method.

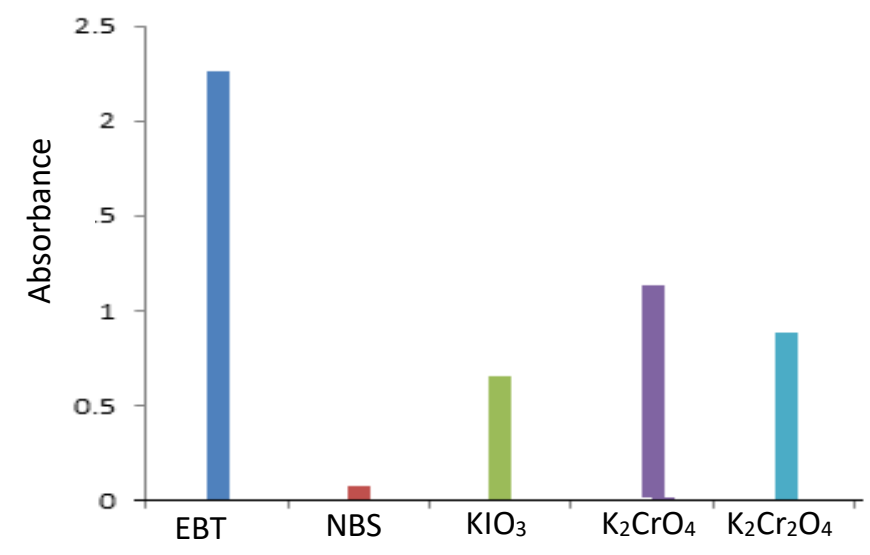

Figure 3: Effect of $1 \mathrm{~mL}$ of $5 \times 10^{-3} \mathrm{M}$ oxidant on the bleaching of $100 \mu \mathrm{gmL}^{-1} \mathrm{EBT}$

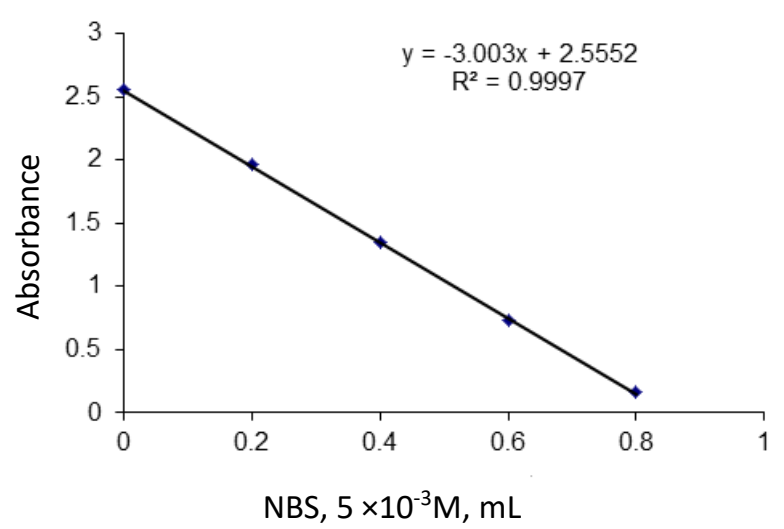

Figure 4: Effect of NBS concentration on the decolonization of $100 \mu \mathrm{gmL}^{-1} \mathrm{EBT}$

\section{Selection of base type and concentration}

The oxidation of drug and dye took place in acidic and basic medium, but it was found that acid has some effect on the bleaching of EBT dye alone, whereas the base no effect. So, the oxidation processes were took place in basic medium. Various bases such as $\mathrm{NaOH}, \mathrm{KOH}, \mathrm{NH} 4 \mathrm{OH}$, and $\mathrm{Na}_{2} \mathrm{CO}_{3}$ of $0.5 \mathrm{M}$ have been tested, using $2 \mu \mathrm{g} \mathrm{mL}^{-1}$ of Paracetamol, to obtain high sensitivity. It was also found that $\mathrm{KOH}$ is the best base for the system (Fig. 5). Also; it was found that $0.5 \mathrm{M}$ concentration gave high absorbance (Fig. 6). The volume of $0.5 \mathrm{M} \mathrm{KOH}$ was studied and found $0.6 \mathrm{~mL}$ is the optimal volume (Fig. 7) and recommended in this method. 


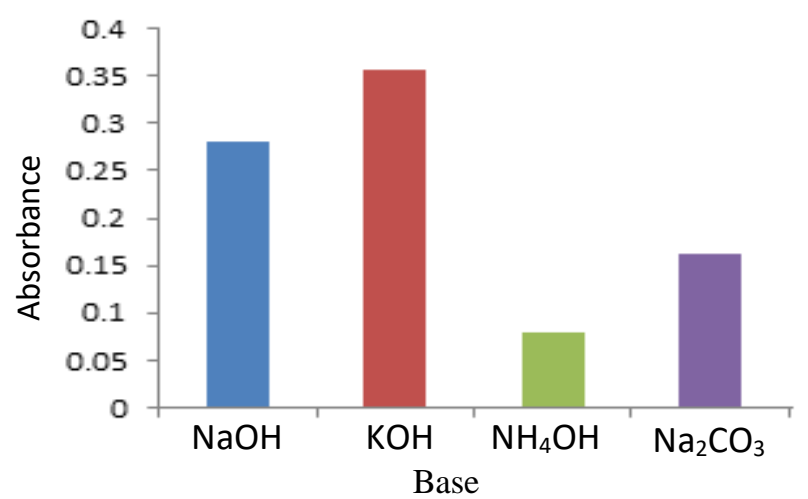

Figure 5: Effect of $1 \mathrm{~mL}$ of $0.5 \mathrm{M}$

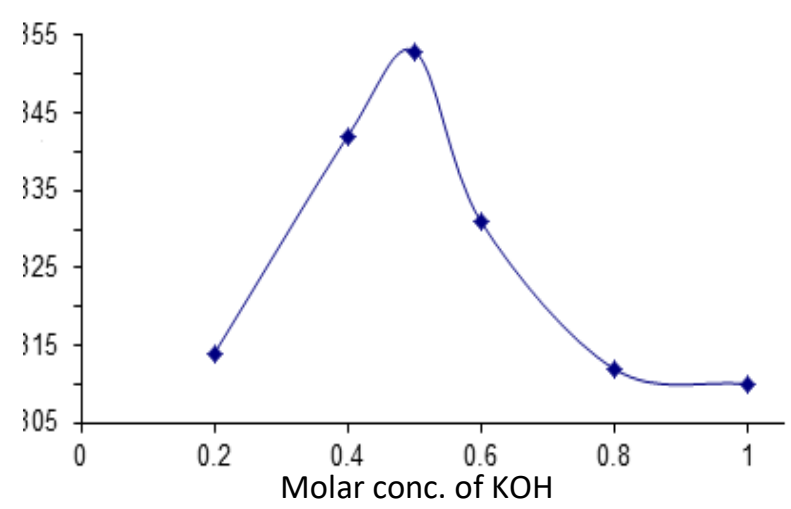

Figure 6: Effect of molar concentration of base on the absorbance

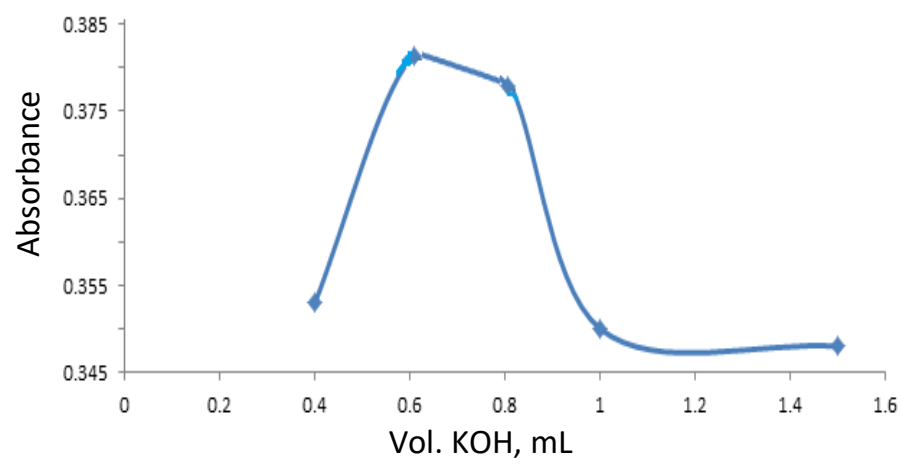

Figure 7: Effect of volume of $0.5 \mathrm{M} \mathrm{KOH}$ on the absorbance

\section{Effect of the sequence of addition}

The sequence of addition was studied; it was found that drug+KOH+NBS+EBT is the best sequence. Whereas other sequences gave lower absorbance value underneath an equivalent experimental conditions.

\section{Effect of oxidation period}

The effect of oxidation period of Paracetamol was studied by addition of $0.5 \mathrm{~mL}$ of $5 \times 10^{-3} \mathrm{M}$ NBS to $2 \mu \mathrm{gmL}^{-1}$ for drug in the presence of $0.8 \mathrm{~mL}$ of $0.5 \mathrm{M} \mathrm{KOH}$. The solution was shaken and left at room temperature for different periods of time. After that $100 \mu \mathrm{gmL}^{-1} \mathrm{EBT}$ was added to the drug, and the solution was shacked and diluted to $10 \mathrm{~mL}$ in calibrated flask. The absorbance of the residual EBT was measured after 10 min standing time at $516 \mathrm{~nm}$ against distilled water. The results showed that 10 min is sufficient for the oxidation of drug and the absorbance remain constant for more than 2 hours.

\section{Quantitation}

Under the described experimental conditions, the standard calibration curve for, Paracetamol with EBT was created by plotting the absorbance versus concentration (Fig.8). Linearity limit and the molar absorptivity value were estimated. Table 1 shows that the method is sensitive, and has an excellent linearity, as the results of the regression equation and the corresponding correlation coefficient, for Paracetamol determination by the proposed method. Accuracy (average recovery \%) and the relative standard deviation (RSD) for the analysis of three replicates of different concentrations for 
Paracetamol explain that the method is accurate and precise. detection limit (LOD) and quantitation limit (LOQ) were calculated by the subsequent equations:

Where:

$$
\mathrm{LOD}=3.3 \sigma / \mathrm{b} \quad \mathrm{LOQ}=10 \sigma / \mathrm{b}
$$

$\sigma=$ standard deviation of the blank

$\mathrm{b}=$ slope of calibration graph.

The results, cited in Table1 are below the lower limit of Beer's law range.

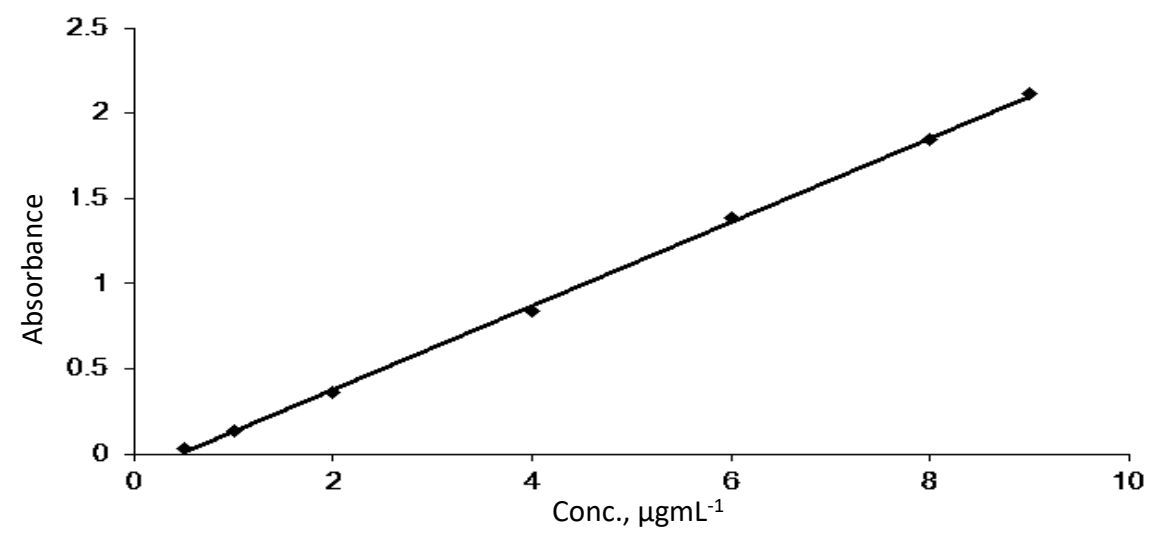

Figure 8: Calibration graph of Paracetamol

Table 1: Quantitative parameters and statistical data for assay of Paracetamol.

\begin{tabular}{|c|c|}
\hline Parameter & Paracetamol \\
\hline Linearity range $\left(\mu \mathrm{gmL}^{-1}\right)$ & $0.5-9$ \\
\hline Molar absorptivity $\left(\right.$ L. $\left.\mathrm{mol}^{-1} . \mathrm{cm}^{-1}\right)$ & $3.719 \times 10^{4}$ \\
\hline Accuracy (Average recovery \%) & 98.57 \\
\hline Precision (RSD) & $\leq 1.5$ \\
\hline LOD $\left(\mu \mathrm{gmL}^{-1}\right)$ & 0.068 \\
\hline $\mathrm{LOQ}\left(\mu \mathrm{gmL}^{-1}\right)$ & 0.229 \\
\hline Correlation coefficient (R) & 0.9994 \\
\hline Regression equation $(\mathrm{Y})$ & $Y=0.246 X-0.114$ \\
\hline Slope & 0.246 \\
\hline Intercept & -0.114 \\
\hline
\end{tabular}

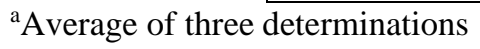

\section{Analysis of Paracetamol in commercial formulations}

The proposed method has been applied for assay of Paracetamol in its commercial formulations ( Injection, syrup, and tablet). The results cited in Table 3 indicated that the proposed method is accurate and reproducible. However; the results of the method were examined statistically by a Student's $t$-test for accuracy by applying the following equation:

$$
t_{\exp }=\frac{|\mu-\bar{X}| \times \sqrt{n}}{s}
$$

Where $\mu$ is the certified value of the $\operatorname{drug}, X, \bar{s}$ and $n$ are the average amount found, standard deviation for five replicates $(\mathrm{n})$ respectively. The results showed in Table 2 that the experimental t-test at the $95 \%$ confidence level, were less than the theoretical value $(t=2.78)$, indicating there is no significant 
deference between certified value $\mu$ and the amount found $X$. Then the confidence interval for the data could be attributed to indeterminate error.

Table 2: Analysis of the Paracetamol in some commercial formulations

\begin{tabular}{|c|c|c|c|c|c|c|}
\hline $\begin{array}{c}\text { Drug } \\
\text { formulation }\end{array}$ & $\begin{array}{l}\text { Present } \\
\text { amount } \\
\left(\mu \mathrm{gmL}^{-1}\right)\end{array}$ & $\begin{array}{c}\text { Recovery }{ }^{*} \\
(\%)\end{array}$ & $\begin{array}{c}\text { Average } \\
\text { recovery } \\
(\%)\end{array}$ & $\begin{array}{c}\text { Drug } \\
\text { content } \\
\text { found }\end{array}$ & $\begin{array}{c}\text { Certified } \\
\text { Value }\end{array}$ & t-test \\
\hline Injection $^{a}$ & $\begin{array}{l}2 \\
8\end{array}$ & $\begin{array}{l}97.15 \\
99.59\end{array}$ & 98.37 & $\begin{array}{c}590.22 \\
\mathrm{mg} / 5 \mathrm{~mL}\end{array}$ & $\begin{array}{c}600 \\
\mathrm{mg} / 5 \mathrm{~mL}\end{array}$ & 0.261 \\
\hline Syrup ${ }^{b}$ & $\begin{array}{l}2 \\
8\end{array}$ & $\begin{array}{l}98.17 \\
99.28\end{array}$ & 99.02 & $\begin{array}{c}1.18 \\
\mathrm{mg} / 5 \mathrm{~mL}\end{array}$ & $\begin{array}{c}1.2 \\
\mathrm{mg} / 5 \mathrm{~mL}\end{array}$ & 1.728 \\
\hline Tablet $^{c}$ & $\begin{array}{l}2 \\
8\end{array}$ & $\begin{array}{l}96.74 \\
99.54\end{array}$ & 98.15 & $\begin{array}{c}490.75 \\
\mathrm{mg}\end{array}$ & $500 \mathrm{mg}$ & 2.716 \\
\hline
\end{tabular}

* Average for three determinations

${ }^{a}$ London Medicals EN LTD, ${ }^{\mathrm{b}}$ NPI Pharma, ${ }^{\mathrm{c}}$ SDI-IRAQ

\section{Selectivity}

The selectivity of the proposed method has been investigated by application of the standard addition procedure for Paracetamol in commercial formulations. The obtained results in Figure 9 and cited in Table 3 indicate no effect of excipients present in formulations for assay of Paracetamol by the proposed method.
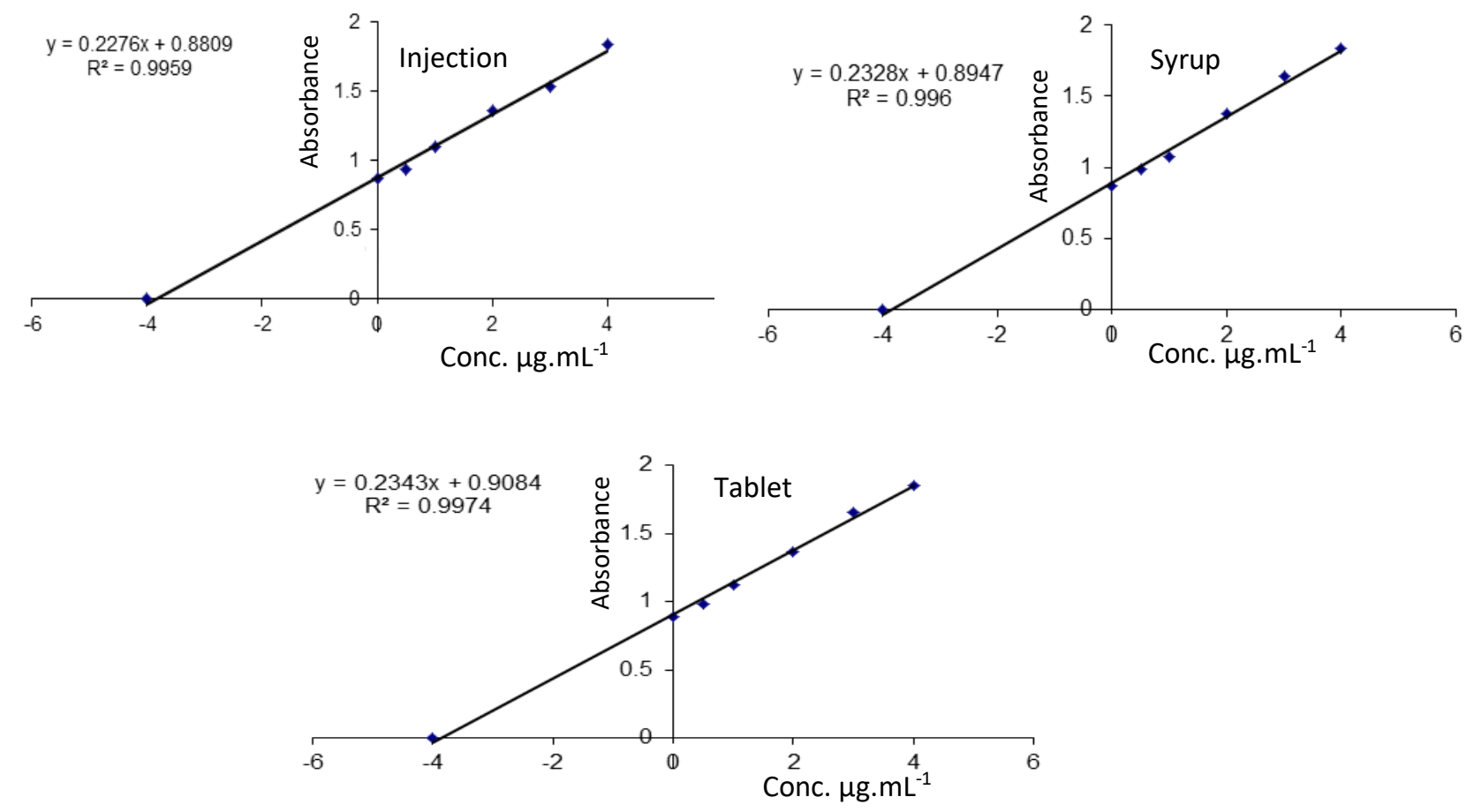

Figure 9: Standard addition procedure for determination of Paracetamol in commercial formulations 
Table 3: Quantification of Paracetamol formulations by the standard addition procedure

\begin{tabular}{|c|c|c|c|c|}
\hline $\begin{array}{c}\text { Pharmaceutical } \\
\text { formulation }\end{array}$ & $\begin{array}{c}\text { Certified } \\
\text { Value } \\
(\mathrm{mg})\end{array}$ & $\begin{array}{c}\text { Amount } \\
\text { Taken } \\
\left(\mu \mathrm{g}_{1} \cdot \mathrm{mL}^{-}\right.\end{array}$ & $\begin{array}{c}\text { Recovery } \\
(\%)\end{array}$ & $\begin{array}{c}\text { Drug } \\
\text { content } \\
\text { found(mg) }\end{array}$ \\
\hline tablet & 500 & 4 & 96.92 & 484.6 \\
\hline Injection & $\begin{array}{c}600 \mathrm{mg} / 5 \mathrm{~m} \\
\mathrm{~L}\end{array}$ & 4 & 96.08 & $\begin{array}{c}576.48 / 5 \mathrm{~m} \\
\mathrm{~L}\end{array}$ \\
\hline Syrup & $1.2 \mathrm{mg} / 5 \mathrm{~mL}$ & 4 & 96.75 & $1.161 / 5 \mathrm{~mL}$ \\
\hline
\end{tabular}

\section{Comparison of the proposed method}

The proposed method has been compared with other spectrophotometric methods, described in the literature, for the determination of Paracetamol, but all of these methods cited in Table 4 suffer from limitations involving for instance, heating, hydrolysis, low sensitivity or tedious.

Table 4: Comparison of the proposed method with some literature methods

\begin{tabular}{|c|c|c|c|c|c|}
\hline Reagent used & $\begin{array}{l}\lambda \max \\
(\mathrm{nm})\end{array}$ & $\begin{array}{l}\text { Linearity } \\
\text { range } \\
\left(\mu \mathrm{gmL}^{-1}\right)\end{array}$ & $\begin{array}{c}\text { Molar } \\
\text { absorptivity } \\
(\mathrm{I} / \mathrm{mol} . \mathrm{cm})\end{array}$ & Remark & $\begin{array}{r}\text { Ref. } \\
\text { no. }\end{array}$ \\
\hline $\begin{array}{c}\text { Water-10\% } \\
\text { methanol }\end{array}$ & 243 & $1-30$ & $2.00 \times 10^{3}$ & $\begin{array}{c}\text { Measurement at UV } \\
\text { region }\end{array}$ & 16 \\
\hline Picric acid & 500 & $5-10$ & $2.60 \times 10^{4}$ & Organic medium & 14 \\
\hline $\begin{array}{l}\text { 3-chloro-7-hydroxy- } \\
\text { 4-methylcoumarin }\end{array}$ & 545 & $0-60$ & $1.20 \times 10^{3}$ & $\begin{array}{l}\text { Involved heating to } 40{ }^{\circ} \mathrm{c} \\
\text { for } 10 \text { min in organic } \\
\text { medium }\end{array}$ & 15 \\
\hline Thymol & 600 & $1-14$ & $6.13 \times 10^{3}$ & Needing acid hydrolysis & 31 \\
\hline $\begin{array}{l}\text { sodium } \\
\text { nitroprusside }\end{array}$ & 700 & $0.19-96$ & $3.40 \times 10^{3}$ & $\begin{array}{c}\text { Standing time } 30 \mathrm{~min} \\
\text { at } 35^{\circ} \mathrm{C}\end{array}$ & 32 \\
\hline $\begin{array}{c}\text { Proposed reagent } \\
\text { (EBT) }\end{array}$ & 516 & $0.5-9$ & $3.70 \times 10^{4}$ & $\begin{array}{c}\text { Sensitive and does not } \\
\text { involve heating or } \\
\text { extraction }\end{array}$ & \\
\hline
\end{tabular}

\section{Conclusion}

A new spectrophotometric method, depending on decolorization of EBT by NBS, has been proposed for determination of Paracetamol in its pure form and pharmaceutical formulations. The method is sensitive, simple, accurate and precise, no extraction or heating is required. Moreover, the method is reliable for the determination of the drug without interference from the common excipients.

\section{ACKNOWLEDGMENTS}

The Authors would like to express their gratitude to the department of chemistry, College of Education for Pure Science, University of Mosul for using their laboratories and providing us the chemicals to carry out the research work. 


\section{Journal of Education and Science (ISSN 1812-125X), Vol: 29, No: 3, 2020 (246-256)}

\section{References}

1. Mangus B. C. and Miller M. G. "Pharmacology application in athletic training”. Philadelphia, Pennsylvania: F.A. Davis., p. 39 (2005).

2. Aghababian R. V. “Essentials of emergency medicine”, Jones \& Bartlett Publishers. p. 814 (2010), Archived from the original on 17 August 2016.

3. Pandolfini C. and Bonati M., Eur. J. pediatr., 164:552-558 (2005).

4. Riano-Galan i., Gonzalez M., Sanchez SG., et al., An. Esp. pediatr., 49:587-593(1998), (in Spain).

5. Song H. and Chen T. S., J. Biochem. Mol. Toxicol., 15:34-40 (2001).

6. Al-Ghabsha T. S., Al-Sabha T. N. and Al-Enizzi M. S., J. Edu. Sci., 17:1-10 (2005).

7. Al-Othman Z. A. and Abdalla M. A., Arab. J. Chem., 4: 239-242 (2011).

8. Al-Abachi M. Q., Al-Safi S. A. and Al-Ward H. S., Iraqi J. Sci., 1 56:2704-2717(2015).

9. Shakir A. H., Dikran S. B. and Ali K. F., Ibn Al-Haitham J. for Pure \& Appl. Si. 23: 277-291 (2010).

10. Thanoon E. S., Raf. J. Sci., 28:76-83 (2019).

11. Ahmed R. K. and Muhammad S. S., Bagh. Sci. J., 12: 317-323 (2015).

12. Dixit R. B. and Patel J. A., IJPSR, 5:2393-2397 (2014).

13. Nagendra P., E J. Chemistry, 8,149-152 (2011).

14. Gloria N., Archi. Pharm \& Pharma Res, 1:1-4 (2018).

15. Divya K., Narayana B. and Sapnakumari M., Inter. Schol. Res.Not., 2013: 6 pages (2013).

16. Saeed A. M., Int. J. Pharm. Sci. Rev. Res., 42:53-57 (2017).

17. Murtaza G. et al., Sci. Res. Ess., 6: 417-421 (2011).

18. Behera S., Ghanty S., Ahmad F., Santra S. and Banerjee S., J Anal Bioanal. Techn., 3:1-6 (2012).

19. Mahood A. M. , Karb. J. pharm. Sci, 12:15-28 (2017).

20. Sahib M. N., Al-Rafi. Univ. Coll. Sci., 37: 301-315 (2016). 
21. Sadok I. and Tyszczuk-Rotko K., Insig. Anal. Electrochem., 1:1-8 (2015).

22. Moghaddam A. B. et al., Microchim. Acta, 171:377-384 (2012).

23. Iranifam M., Khodaei S. and Saadati M., Microchem. J., 146:850-855( 2019).

24. Ruengsitagoon W., Liawruangrath S. and Townshend A., Talanta, 69:976-983 (2006).

25. Sayed R. A., Hassan W. S., EL-MammLi M. Y. and Shalaby A. A., Orien. J. Chem., 28:639-650 (2012).

26. Omer L. S. and Ali R. J., Inter. J. Chem., 9:49-61 (2017).

27. El-Didamony1A. M., Hafeez S. M. and Ali I. I., J. Appl. Pharm. Sci., 5: 026-033 (2015).

28. Umamaheswar K., Naganjaneyulu T. and Rambabu C., Glob. J. Pharmaceu. Sci., 2:1-5 (2017).

29. Rahman N., Khatoon A. and Rahman H., Quim. Nova, 35:392-397 (2012).

30. Rele R. V. and Sachin Patil S., Der Pharma Chemica, 4:2278-2282 (2012).

31. Omar F. Kh., Iraq. Nati. J. Chem., 53:36-42 (2014).

32. Zhan Y., Zhang Y., Li Q. and Du X., J. Anal. Chem., 66:215-220 (2011). 